\title{
SCHOOL PRINCIPAL'S LEADERSHIP BEHAVIOR IN PSYCHOLOGY PERSPECTIVE
}

\author{
Vonny Angeli Sudharta \\ Department of Educational Management \\ State University of Malang, Indonesia \\ vonnysudharta@gmail.com
}

\author{
Amalia Rosidah \\ Department of Educational Management \\ State University of Malang, Indonesia \\ amaliarosidah99@gmail.com
}

\author{
Maria Mujiati \\ Department of Primary Teacher \\ State University of Malang, Indonesia \\ mujiatimaria96@gmail.com
}

\begin{abstract}
The purpose of this study was to describe the characteristics of principal leadership, to describe the psychological characteristics of the principal's leadership, and to design the leadership model of the principal in a psychological perspective. The research was conducted in Public Senior High School 1 Malang. The research method used is qualitative research with case study design. Technique of data retrieval through interview, observation, and documentation. The data analysis used is interactive model analysis. The results show that the leadership characteristics shown by the principal are objective, democratic, friendly, humorous, honest, disciplined, assertive, able to control emotions, appreciate, motivate, have a family attitude to all members, fair, strong and religious. Based on the psychological characteristics of the principal's leadership is a leader who shows the person calm, relaxed, patient, meticulous, not easily affected, and high self-awareness. Principal leadership models in psychological perspectives reflect a attribute sanguine and phlegmatic.
\end{abstract}

Keywords: leadership behavior, psychology perspective

\section{INTRODUCTION}

The existence of a leader is needed in an organization, this is because leaders who will determine the direction of the organization will be taken. Leadership itself is a person's activities in influencing and moving all its members to be able to achieve the goals set. Leadership is understood as the power to mobilize and influence people (Zainal, et al., 2014). The leader in the educational institution is the principal. The principal must be able to mobilize all the citizens of the school to achieve the educational goals. This is confirmed by Suharsaputra (2016) which states that the leadership makes an organization can move in a directed direction in order to achieve the goals set. Educational leadership is conducted in educational institutions, with the aim of influencing all school citizens to carry out their duties and work properly and correctly in accordance with their respective responsibilities, which ultimately aims to develop all the potential possessed by learners (Gunawan, 2015b).

Leadership shown by the principalship determines the quality of learning in the classroom implemented by the teacher or not (Gunawan, 2015c). Each principal has a different style of leadership and no leadership style is most effective or effective, because it all depends on the situation and condition of each subordinate. As revealed by Suharsaputra (2016) who argued that a leader can achieve goals in various ways and styles in the lead, in accordance with internal conditions and external challenges it faces, so that effective leadership can not be attributed to only certain aspects of the leader Or environmental conditions that surround it. Wahjosumidjo (2013) asserted leadership can be divided into four approaches, namely: (1) psychological approach (psychological approach); (2) situational approach (situational approach); (3) behavioral approach; and (4) a contingency approach. Leadership based on a psychological perspective means looking at the psychological side that the principal has in terms of leadership, where the observation in the psychological principal is how to motivate, how to make decisions, and how to communicate. Psychology itself is keadan of one's self which can be known with visible activities but there is also an implied or visible. A similar point is expressed by Kusmintardjo (1989) that the leader is effective (effective) is the source of the personality of the leader himself as a human being. This proves that the most influential thing in leadership of the principal is the personality of the principal himself. Yulk (2001) asserts personality traits are especially relevant to successful leadershi. Personality traits are considered highly relevant to leadership success. Leadership is considered good when leadership functions are run on ethical principles (Gunawan, 2015a).

Leadership of the principal will appear when the principal interacts with others, such as having a private conversation with the teacher, his / her peers, and with his students (Gunawan, 2014b). Effective principalship are the principals of the school and constantly focuses on learning and teacher performance (Gunawan, 2015c). Good leader is good person (Gunawan and Benty, 2017). Leadership psychology deals with: the personal characteristics of leaders; The nature of the relation between leaders and followers; Why do we perceive some people to be better leaders than others; What are the circumstances that evoke leadership qualities in people; and can leadership be taught (Messick and Kramer, 2005). The psychology dimension of leadership is thought to be uniquely important because of the leaders' potential to influence 
employee and organizational behavior (Ozbag, 2016). The leaders are required to support the employee's involvement for accelerating the change in organization (Hussain, et al., 2016).

The psychology of leadership is defined as the demonstration of normative action through personal communication and interpersonal relationships, and the promotion of the conduct of followers through two-way communication reinforcement, and decision-making (Brown, et al., 2005). The formulation of the problems asked in this study are: (1) what are the characteristics of the principal's leadership? (2) what are the characteristics of headmaster leadership in a psychological perspective? and (3) how does the headmaster model model in a psychological perspective?

\section{METHODS}

The research design used in this research is the research using qualitative descriptive approach and the type of case study research in SMA Negeri 1 Malang. . The research location addressed at Jalan Tugu No. 1 Malang City East Java. Data sources include school principals, vice principals of curriculum sections, vice principals of student affairs, vice principals of facilities and infrastructure, vice principals of school and community relations, teachers and students. Data collection techniques are interviews, observations, and documentation techniques. These techniques are the basic techniques in the collection of qualitative data.

The researcher becomes the key instrument during the data collection process. The presence of researchers in the field is one benchmark of success will be the understanding of the phenomena that occur in schools, because the collection of data must be done in the actual situation. Ulfatin (2015) confirms in qualitative research that humans act as key instruments or primary data-gathering tools. The researcher himself acts as a key instrument. Researchers as a tool or a key instrument in research, so its presence in the background research is absolutely done.

Data analysis is done when starting to enter the field, during the field, and after finished in the field. However, this data analysis is more focused during the on-site process along with data collection. Analysis of qualitative data is done simultaneously with data collection process take place, meaning that activities are also conducted during and after data collection (Gunawan, 2014a). Data analysis used is interactive model from Miles, et al., (2014) namely: data reduction, data presentation, and verification.

\section{RESULTS}

\section{A. Characteristics of Principal Leadership}

The leadership qualities displayed by the principal are objective, democratic, friendly, humorous, honest, disciplined, assertive, able to control emotions, appreciate, motivate, have a kinship to all members, fair, strong and religious. Leadership held by the principal is prophetic leadership. Nevertheless, the principal still shows himself as a figure that makes no distinction between one another. The principal is a democratic, objective, friendly, humorous leader, does not impose a will, is able to position himself, and is able to treat subordinates according to his subordinates. It is the principal's superiority that is religious in the lead. The following is an excerpt of an interview transcript to the teacher.

Researchers ask, "Are you able to control your emotions when facing problems at school?, Teacher say "He usually calls personally. Usually approach through religion. Yes, for example facing this naughty child, there must be a reason, trying to explore why this child like that. If I meet it is reminiscent of sholawat, yes, Al Fatihah, if you want to teach, let science barokah".

The principal demonstrates democratic leadership. The principal tries to get closer to the school people. The principal also has the authority to be able to control his subordinates. The principal leads with kinship and embraces all the citizens of the school, so the teachers, staff, and students do not feel depressed and very comfortable. In addition, the principal also has a religious background. The principal is also a kyai, so the policies applied are also shown from the religious side. The principal also includes an honest person in carrying out his duties, in the sense that the school can be trusted in carrying out duties and obligations. The principal also provides the mandate or duty to the subordinates, by dividing the tasks in school as well as possible. Division of tasks based on the competencies of teachers and staff. The following is an excerpt of an interview transcript to the Vice Principal for Student and Vice Principal Field of Curriculum.

\begin{tabular}{|c|c|}
\hline Researcher & $\begin{array}{l}\text { Does the principal establish a good } \\
\text { relationship with all school } \\
\text { residents? }\end{array}$ \\
\hline Student Vice Principal & $\begin{array}{l}\text { Every Friday there is a regular } \\
\text { meeting with the headmaster of the } \\
\text { school, the principal and the vice } \\
\text { principal discussing the course of } \\
\text { the school for a week. Discuss if } \\
\text { there are difficulties. With his } \\
\text { honesty he does not discriminate, so } \\
\text { a kyai knows exactly how to put } \\
\text { himself in the act and behave. }\end{array}$ \\
\hline Vice principal of Curriculum & $\begin{array}{l}\text { : He often gives advice related to the } \\
\text { life that must be lived by Mr } \\
\text { Mother, for example the work must } \\
\text { be sincere, described by what name } \\
\text { is the activity ever executed by } \\
\text { Rasulullah, for example like that. }\end{array}$ \\
\hline
\end{tabular}

Characteristics of Principal Leadership in Psychological Perspective based on the psychological characteristics of the principal's leadership shows the person who is calm, relaxed, patient, meticulous, not easily affected, and high self-awareness. The personality displayed by the principal is a person who is not in a hurry, Motivator, have a familial attitude to all members, fair, strong, and religious. The leadership applied by the principal is judged according to the expectations of his subordinates. This can be seen from the ability of the principal to position himself, be democratic, objective, friendly, humorous, not impose the will, and able to treat subordinates according to the person of his subordinates. Through these things will create a harmonious work situation, and will be able to work effectively and efficiently. If it is realized then the 
principal will be able to influence and move his subordinates to work in accordance with the goals set.

\section{B. Leadership Model Headmaster in Psychological Perspective}

The findings of the study show that the school principal's effective leadership model in a psychological perspective is a school principal that reflects the leadership of sanguin and plegmatist attributes (Figure 1). The sanguin attribute is the character of a leader who has an aggressive nature. The aggressive attitude in question is a spiritful and full of initiative.

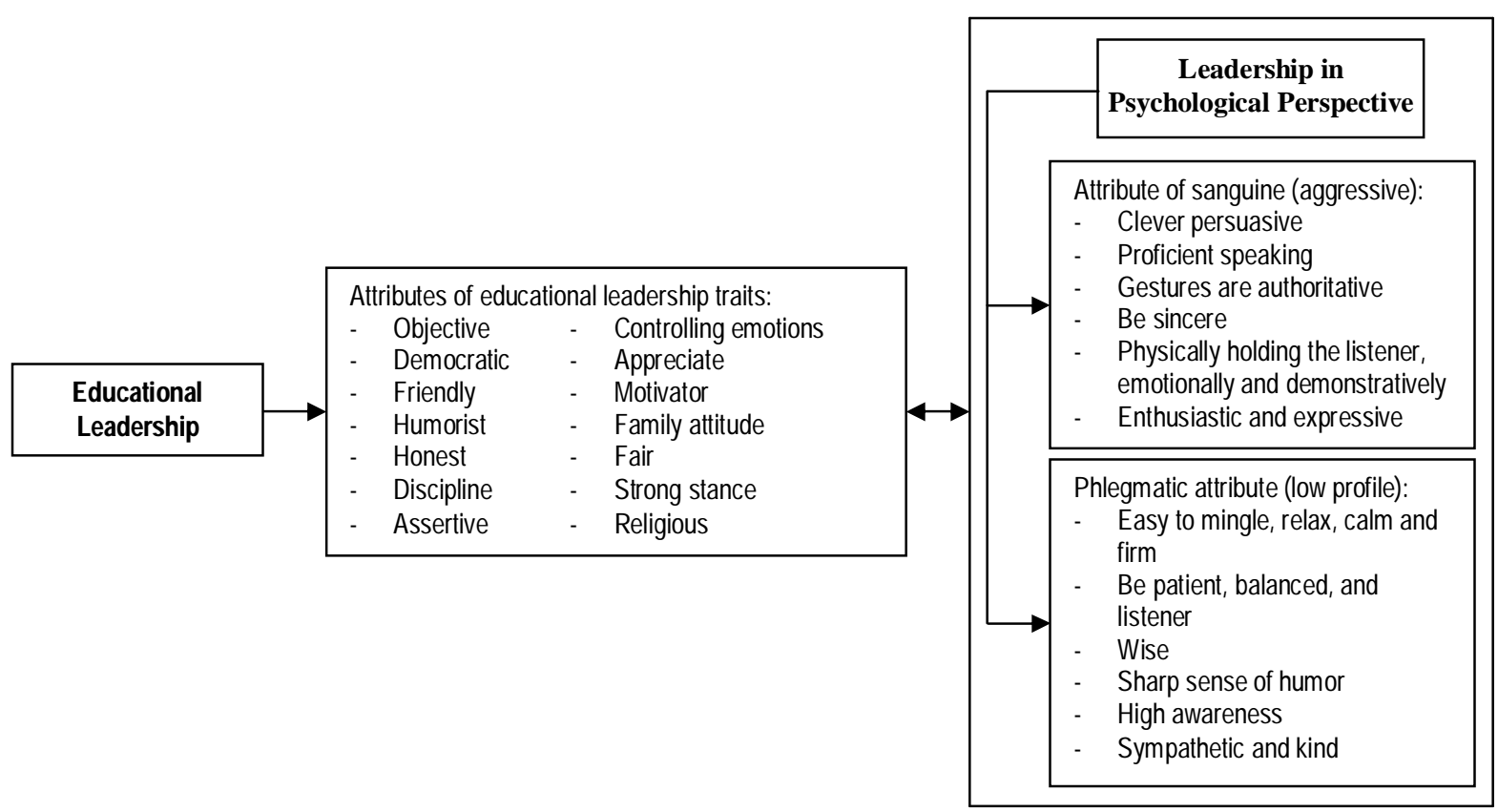

Figure 1

Leadership Model Headmaster in Psychological Perspective

\section{DISCUSSION \\ A. Characteristics of Principal Leadership}

The first findings are in harmony with the theory of leadership that is based on the theory of traits (traits theory). The theory of attitudes views leadership as a combination of innate or character traits and focuses on the ownership of a personality, social, physical, or intellectual character that distinguishes leaders from non-leaders (Gunawan and Benty, 2017). The qualities of a leader are characteristics that point to a number of individual attributes of a leader that differentiate the nature of effective leaders with ineffective leaders (Usman, 2007). The theory of nature assumes that what makes one leader successful (effective) is the source of the personality (personality) of the leader himself as a human being (Kusmintardjo, 1989). The same thing is put forward by Hughes et al. (2002) who states that effective leaders are leaders who have a personality characterized by good traits and are present in five factors of personality model: chaos (Surgability), recognition (agreeableness), dependability, adjustment, and intellect (intellectance).

Kouzes and Posner (2002) based on the results of his research concluded the characteristics of good leaders are: (1) looking forward (visionary); (2) honest; (3) proficient; And (4) inspires. While Yulk (2002) states that the properties of effective leaders are: (1) the need for affiliation; (2); Emotional stability; (3) confident; (4) personality integrity; (5) moderate achievement orientation; (6) strong energy and tolerance to stress; (7) motivation; (8) internal locus of control; and (9) maturity. The same thing is put forward by Gibson, et al., (2003) which states the qualities of effective leaders are: (1) ability; (2) personality; and (3) motivation. Miru (2006) states a leader must be a person of honesty; People who function reason; People must have courage; and the rich in the broadest sense. A number of studies have linked personality traits and attributes to leaders of ethical behavior, providing a substantial empirical foundation for the argument that (Brown, et al., 2005; Walumbwa and Schaubroeck, 2009; Ozbag, 2016).

Traits are more likely to predict leadership when integrated in meaningful ways (Zaccaro, 2007). Leadership makes an organization able to move directed in an effort to achieve goals that have been set (Suharsaputra, 2016). Educational leadership has a crucial role in governance and education, and what distinguishes the concept of educational leadership with leadership in other areas is that the core of educational leadership is educational (Gunawan, 2016a). Principals to focus on the principles of educational leadership by considering the values and ethics of leadership to create a climate of school work was good, make quick decisions and precise, confident, able to manage infrastructure, and exercise its authority as an educational leader (Kusumaningrum, Et al., 2016). 
Characteristics of Principal Leadership in Psychological Perspective

The research findings show that based on the psychological perspective, the leadership performed by the principal shows that the principal is a calm, relaxed, patient, conscientious, not easily affected, and high selfawareness. This causes the principal to become a respected figure and a role model for his subordinates. As leaders must be able to move, direct, guide, protect, nurture, model, encourage, and provide assistance (Wahjosumidjo, 2013). The role of the principal in presenting the nature and behavior of leadership becomes the determining factor of school success in achieving the goal (Gunawan, 2016c). The leadership of the principal becomes decisive and crucial factor in developing the school quality (Gunawan, 2017a). Leadership model implemented principals become the key school to achieve the goals of the school (Gunawan, 2016b)

Wawo Runtu (2003) based on the results of his research concluded that the personality factors of a leader Which can influence its success in leading the organization is a carrier of change, communication, leadership in work, networking, developer of others, influence, teamwork, diversity, local language use, commitment, discipline, mastering information technology, exemplary, optimism, mutual love, and consistency. In addition, the motivation of subordinates is an important thing that must be known by a leader, so that leaders can influence them to participate in organizational change programs initiated by a leader. A better understanding of the change agent 's psychological motivations and his / her collaboration with other employees may contribute to the understanding of how to increase the social proprietary within companies (Witjes, 2015). Leadership involves motivating others to work collaboratively in the pursuit of a common goal (Vroom and Jago, 2007).

Leaders emerge in a system that also involves willing followers and groups, express core values, display creativity and resilience, and in a sense are performance artists (Bennis, 2007). A system model of leadership, providing an understanding of leadership as a set of decision processes embodying wisdom, intelligence, and creativity, as well as higher cognitive processes (Sternberg, 2007). Ramadhani (2017) based on the results of his psychological research and the soul of a person to influence the decision that must be made. Spiritual leadership is correlated with leadership effectiveness, as assessed by their staff, was significant after controlling for organization variables (organization size and growth) and personality (Amram, 2009).

Prophetic leadership conducted by the principal can be seen from the way the principal in acting and making decisions, where the principal always imitate leadership conducted by the Prophet Muhammad. Exemplary that can be taken from the Prophet Muhammad is the strength of faith, courage, patient, steadfast, and noble (Rivai and Arifin, 2009). Various efforts made by the principal in achieving the educational goals that have been achieved, principals always strive to be able to behave as the leadership of the Prophet. Among them are working sincerely, not angry when there are subordinates who disappoint, provide advice, and motivation through hadith-hadist. As in the context of Islamic education organizations, leadership is a process of achieving mutually agreed objectives according to ethical-quranic (Baharuddin and Umiarso, 2016). The leadership of principalship is the factor that affects the performance of teachers to teach (Gunawan, 2017b).

\section{B. Leadership Model Headmaster in Psychological Perspective}

Sanguine types greater optimism (Howart, 1988). The plegmatic attribute is the character of a leader who has a low profile. Phlegmatics less state anxiety and least depression (Howart, 1988). The combination of sanguen and plegmatic nature makes one who works hard, speaks, acts, visionary, and keeps humble. Kant shares personality into two, namely: (1) temperament of emotions that include sanguine; and (2) the temperament of activity that included phlegmatics (Vorkapić, 2011). Sanguine (stable extraverts) as sociable, lively, carefree, leadership, outgoing, talkative, responsive and easygoing (Revelle, et al., 2011; Vorkapić, 2011). Sanguinis have the characteristic of life, friendly, quick action (Sujanto, et al., 2001). Some strengths of the sanguine temperament are: (1) he is enjoys life; (2) he is optimistic; (3) he is friendly; (4) he is compassionate; and (5) he is extrovert (Cantrell, 2001). The characteristic of sanguine is strong balanced mobile and stable extravert (Ruch, 1992). The characteristics of an emotional sanguine, an interesting personality, like to talk, great sense of humor, strong memory, physically appealing to the listener, emotional and demonstrative, enthusiastic and expressive, cheerful and full of curiosity, life in the day Now, be sincere (Hasanah, 2014).

Phlegmatic (stable introverts) as passive, careful, thoughtful, peaceful, controlled, reliable, eventempered and calm (Revelle, et al., 2011; Vorkapić, 2011). Plegmatic characteristic is not to hurry (calm, calm), not easily influenced, and faithful (Hasanah, 2014). Some strengths of flip phlegmatic are: (1) he is witty; (2) he is easy going; (3) he is dependable; (4) he is very practical and efficient; and (5) he is neat (Cantrell, 2001). Plegmatic atribut has a kind heart, his personality is quietly humble and also patient, looks calm, has a high humor, and is fun to invite slang (Karina, 2015). The characteristics of an emotionally plegmatist, humble, patient, well balanced, consistent, calm but intelligent, sympathetic and kind, hide emotions, and happy to receive life (Hasanah, 2014).

\section{CONCLUSION}

Based on the results of the research can be concluded that the principal applying prophetic leadership style. Attributes of leadership that appear to the principal are religious, objective, democratic, friendly, humorous, and honest. From a psychological perspective, the principal presents a quiet personality, does not like to be hasty, patient, meticulous, unemotional, easy to smile and soft-spoken. Based on the emotional known principals featuring leaders who have strong opinion, high self-awareness and connect 
with the religious aspects. Based on this it can be seen that the principal is a leader who has a patient personality, meticulous, calm, and not emotional. The very strong religious values of the headmaster's self appear in worship on time, guided by beliefs based on religious values, and teaches to work sincerely with the diniati worship.

\section{REFERENCES}

[1] Amram, J. Y. 2009. The Contribution of Emotional and Spiritual Intelligences to Effective Business Leadership. Dissertation. California: Institute of Transpersonal Psychology.

[2] Baharuddin, and Umiarso. 2016. Kepemimpinan Pendidikan Islam: Antara Teori dan Praktik. Jogjakarta: Ar-Ruzz Media.

[3] Bennis, W. 2007. The Challenges of Leadership in the Modern World: Introduction to the Special Issue. American Psychologist, 62(1), 2-5.

[4] Brown, M. E., Trevino, L. K., and Harrison, D. A. 2005. Ethical Leadership: A Social Learning Perspective for Construct Development and Testing, Organizational Behavior and Human Decision Processes. Journal of Business Ethics, 97: 117-134.

[5] Cantrell, P. E. 2001. A Study of Temperament: From a Biblical Viewpoint. Pennsylvania: Eleven Lessons.

[6] Gibson, J. L., Ivancevich, J. M., Donnelly, J. H., and Konopaske, R. 2003. Organizations: Behavior, Structure, Processes. New York: McGraw Hill, Inc.

[7] Gunawan, I. 2014a. Metode Penelitian Kualitatif: Teori dan Praktik. Jakarta: PT Bumi Aksara.

[8] Gunawan, I. 2014b. Pengaruh Supervisi Pengajaran dan Kemampuan Guru Mengelola Kelas terhadap Motivasi Belajar Siswa. Ilmu Pendidikan Jurnal Kajian Teori dan Praktik Kependidikan, 41(1), 44-52.

[9] Gunawan, I. 2015a. Mengembangkan Kepemimpinan Kepala Sekolah Berbasis Nilai dan Etika. Proceeding National Seminar and International Conference Scientific Forum-Faculty of Education Department of Science Educatioin (FIP-JIP), Faculty of Education, State University of Gorontalo, Gorontalo, 9-11 September, p. 302-312.

[10] Gunawan, I. 2015b. Pengaruh Kepemimpinan Transformasional dan Kepuasan Kerja terhadap Perilaku Kewargaan Organisasi Guru Sekolah Dasar. Premiere Educandum, 5(1), 59-81.

[11] Gunawan, I. 2015c. Values and Ethics in Educational Leadership: An Idea of Character Building of Students. Conference Proceedings Character Education in Indonesia Concepts and Applications in Primary Schools, IKIP PGRI MADIUN, 9 June, p. 1-13.

[12] Gunawan, I. 2016a. Merevitalisasi Kepemimpinan Pancasila dalam Bidang Pendidikan. Prosiding Seminar Nasional Penguatan Manajemen Pendidikan di Era Kompetisi Global, Jurusan Administrasi Pendidikan Universitas Negeri Malang, 12 March, p. 67-84.

[13] Gunawan, I. 2016b. Model of Educational Leadership in the Implementation of Curriculum 2013. Proceedings The 4th International Conference Language, Society, and Culture in Asian Contexts (LSCAC 2016) on Cultivating and Casting Asian Diversities: Empowering the Asians, 24-25 Mei, p. 1109-1118.

[14] Gunawan, I. 2016c. Pasaran: Menggali Nilai-nilai Permainan Tradisional dalam Mengembangkan Sifatsifat Kepemimpinan Pendidikan. Jurnal Studi Sosial, $8(1), 55-64$.

[15] Gunawan, I. 2017a. Instructional Leadership Profile of Junior High School's Principal (A Case Study of Junior
High School in Malang). International Research-Based Education Journal, 1(1), 64-68.

[16] Gunawan, I. 2017b. Instructional Management in Indonesia: A Case Study. Journal of Arts, Science and Commerce, 8(1), 99-107.

[17] Gunawan, I., and Benty, D. D. N. 2017. Manajemen Pendidikan: Suatu Pengantar Praktik. Bandung: Alfabeta.

[18] Hasanah, I. I. 2014. Kepribadian Manusia. Retrieved June 13, 2017, http://digilib.uinsby.ac.id/1964/5/Bab\%202.pdf).

[19] Howart, E. 1988. Mood Differences between the Four Galen Personality Types: Choleric, Sanguine, Phlegmatic, Melancholic. Personality and Individual Differences, 9(1), 173-175.

[20] Hughes, R. L., Ginnett, R. C., and Curphy, G. J. 2002. Leadership Enchancing: The Lessons Experience. New York: McGraw Hill, Inc.

[21] Hussain, S. T., Lei, S., Akram, T., Haider, M. J., Hussain, S. H., and Ali, M. 2016. Kurt Lewin's Process Model for Organizational Change: The Role of Leadership and Employee Involvement: A Critical Review. Journal of Innovation and Knowledge, 46(2), 17.

[22] Karina, S. 2015. Mengenal Kepribadian Manusia (Melankolis dan Plegmatis). Retrieved June 13, 2017, http://karin.student.akademitelkom.ac.id/wpcontent/uploads/kalins-pdf/singles/mengenalkepribadian-manusia-melankolis-plegmatis.pdf.

[23] Kouzes, J. M., and Posner, B. Z. 2002. The Leadership Challenge. San Francisco: Jossey-Bass Publishers.

[24] Kusmintardjo. 1989. Kepemimpinan dalam Pendidikan. In Soekarto, I., dna Soetopo, H., (Ed.), Administrasi Pendidikan (p. 251-279). Malang: Penerbit IKIP Malang.

[25] Kusumaningrum, D. E., Sumarsono, R. B., and Gunawan, I. 2016. Principal Empowerment Through Soft System Methodology Approach. Proceeding International Conferences on Education and Training, 2nd ICET Theme: Improving the Quality of Education and Training Through Strengthening Networking, 4-6 November, p. 205-211.

[26] Messick, D. M., and Kramer, R. M. 2005. Introduction: New Approaches to the Psychology of Leadership. In Messick, D. M., dan Kramer, R. M., (Ed.)., The Psychology of Leadership: New Perspectives and Research (p. 1-10). New Jersey: Lawrence Erlbaum Associates, Publishers.

[27] Miles, M. B., Huberman A. M., and Saldana, J. 2014. Qualitative Data Analysis: A Methods Sourcebook. New York: SAGE Publications, Inc.

[28] Miru, S. 2006. Kajian Kepemimpinan Kaitannya dengan Total Quality Management Perusahaan Cold Storage Eksportir Udang di Makassar. Analisis, 3(1), 53-60.

[29] Ozbag, G. K. 2016. The Role of Personality in Leadership: Five Factor Personality Traits and Ethical Leadership. $12^{\text {th }}$ International Strategic Management Conference (ISMC 2016), 28-30 October, Antalya, Turkey, Procedia - Social and Behavioral Sciences, Retrieved June 13, 2017, http://www.sciencedirect.com.

[30] Ramadhani, A. 2017. Logika Hubungannya dengan Psikologi dan Kepemimpinan. Retrieved June 13, 2017, http://informatika.stei.itb.ac.id/ rinaldi.munir/Matdis/20 07-2008/Makalah/MakalahIF2153-0708-033.pdf.

[31] Revelle, W., Wilt, J., and Condon, D. M. 2011. Individual Differences and Differential Psychology: A Brief History and Prospect. Dalam Chamorro-Premuzic, T., VonStumm, S., dan Furnham, A., (Ed.)., The WilleyBlackwell Handbook of Individual Differences (p. 3-38). London: Blackwell Publishing, Ltd. 
[32] Rivai, V., and Arifin, A. 2009. Islamic Leadership: Membangun Super Leadership melalui Kecerdasan Spiritual. Jakarta: PT Bumi Aksara.

[33] Ruch, W. 1992. Pavlov's Types of Nervous System, Eysenck's Typology and the Hippocrates-Galen Temperaments: An Empirical Examination of the Asserted Correspondence of Three Temperament Typologies. Personality and Individual Differences, 13(12), 1259-1271.

[34] Sternberg, R. J. 2007. A Systems Model of Leadership: WICS. American Psychologist, 62(1), 34-42.

[35] Suharsaputra, U. 2016. Kepemimpinan Inovasi Pendidikan: Mengembangkan Spirit Enterpreneurship Menuju Learning School. Bandung: PT Refika Aditama.

[36] Sujanto, A., Lubis, H., and Hadi, T. 2001. Psikologi Kepribadian. Jakarta: PT Bumi Aksara.

[37] Ulfatin, N. 2015. Metode Penelitian Kualitatif di Bidang Pendidikan: Teori dan Aplikasinya. Malang: Media Nusa Creative.

[38] Usman, H. 2007. Faktor-faktor yang Mempengaruhi Perilaku Kepala Sekolah. Jurnal Tenaga Kependidikan, 2(3), 1-20.

[39] Vorkapić, S. T. 2011. Electrophysiological Differences in Sanguine, Choleric, Phlegmatic and Melancholic. Romanian Journal of Psychology, Psychotherapy and Neuroscience, 1(2), 67-96.

[40] Vroom, V. H., and Jago, A. G. 2007. The Role of the Situation in Leadership. American Psychologist, 62(1), 17-24.

[41] Wahjosumidjo. 2013. Kepemimpinan Kepala Sekolah: Tinjauan Teoretik dan Permasalahannya. Jakarta: PT Rajagrafindo Persada.

[42] Walumbwa, F. O., and Schaubroeck, J. 2009. Leader Personality Traits and Employee Voice Behavior: Mediating Roles of Ethical Leadership and Work Group Psychological Safety. Journal of Applied Psychology, 94(5), 1275-1286.

[43] WawoRuntu, B. 2003. Determinan Kepemimpinan. Makara, Sosial Humaniora, 7(2), 71-81.

[44] Witjes, S. 2015. A New Psychology for Sustainability Leadership: The Hidden Power of Ecological Worldviews. Journal of Cleaner Production, 45(2), 1-2.

[45] Yulk, K. 2001. Leadership in Organization. New Jersey: Prentice Hall Inc.

[46] Yukl, G. 2002. Leadership in Organizations. Upper Sadle River, New Jersey: Prentice Hall.

[47] Zaccaro, S. J. 2007. Trait-Based Perspectives of Leadership. American Psychologist, 62(1), 6-16.

[48] Zainal, V. R., Hadad M. D., and Ramly, M. 2014. Kepemimpinan dan Perilaku Organisasi. Jakarta: PT Rajagrafindo Persada. 